\title{
ENVISIONING THE KHALSA STATE MODELED AFTER THE VATICAN STATE: SEEKING THE GOODWILL OF THE INDIAN GOVERNMENT
}

\author{
TENNYSON SAMRAJ \\ Burman University, Lacombe, \\ Alberta Canada
}

https://doi.org/10.37602/IJSSMR.2020.3604

\begin{abstract}
This paper intends to present a practical solution to the aspirations of the Sikh community of believers. The three facets of this study are: (1) The Sikhs' aspiration for a Khalsa state, where they can define, defend, and practice Sikhism. (2) The Sikhs' yearning that the Harmandir Sahib (Akal Takht - the throne of the timeless one) and the Golden Temple complex be the supreme centre and seat of authority of Sikhism. (3) The Sikhs' wish to work and worship with fellow Indians who live within the Punjab state and the rest of India, their country. Sikhs can achieve these aspirations by seeking the 'goodwill' of the Indian Government. To this end, it is proposed: (1) to create the Khalsa State modeled after the Vatican state, where the Chief Guru, like the Pope, can be both the temporal head of the Khalsa state and the spiritual leader of the Sikhs in India and around the world. The Khalsa state is created from the area around the Harmandir Sahib Temple of Amritsar, modeled like the Vatican state around St Peter's Cathedral. (2) The Punjab state government continue and maintain the current relationship with the federal or central Government of India. (3) The Khalsa State accept India's sovereignty and consign foreign policy to the Indian Government. This would create a religious haven for the Sikh people, similar to the Vatican state for Catholics.
\end{abstract}

Keywords: Vatican State, Khalsa State, Secular State, Akal Takht, Akal Dal, holy land

\subsection{INTRODUCTION: A PLAUSIBLE SOLUTION}

Sikhs' aspirations of the Khalsa Ideal and state ${ }^{1}$ can be resolved in the context of India's goodwill. $^{2}$ India is known as the land of religions; the story of India is the story of religions. ${ }^{3}$ Here are some ideas that can achieve Sikhs' aspirations for gaining religious, social, and economic freedom within the framework of India. What the Sikhs want must be understood in the context of what needs to be done for the Sikhs. The Indian Government can solve the problem if the issue of sovereignty is not debated. The Indian Government and the expatriate

\footnotetext{
${ }^{1}$ Hardev Singh Virk, The Khalsa Ideal -State and Democracy. (Sikhnet, 2015) 14.

${ }^{2}$ India as a regional power is known for its religious tolerance. India has been a secular country allowing many religions to live side by side. In the lotus temple in Delhi people of all religions are allowed to come and worship.

${ }^{3}$ India is birthplace, of Buddhism Jainism, Sikhism and is the home of Hinduism where also millions of Muslims dwell.
} 


\section{International Journal of Social Sciences and Management Review}

Volume: 03, Issue: 06 “November - December 2020”

ISSN 2582-0176

outside of India have not succeeded in ending the civil conflict between Sikhs and the fellow Indians because the starting point has always been the question of Sikhs' quest for a nation (quam) ${ }^{4}$. Nationalism is a given aspiration in modern society where religion, land, race, language, and ideology play a significant role. However, Sikh nationalism or quam ${ }^{5}$ (nation) entails two issues, political freedom and religious freedom. To resolve the two issues-both these concerns must be dealt with separately. The Sikhs through the Akal Dal have an elected political state in India, and that should continue. The question is, should the Akal Takht ${ }^{6}$ (seat of religious authority) along with the Akal Dal (the political wing of the Sikhs) be allowed to establish the Khalsa state-- land of the pure ${ }^{7}$. The Vatican model can provide the basis for allowing the Sikhs to create a sovereign state like the Vatican state, where the spiritual leader is the temporal head of the Akal Takht and the spiritual head of the Sikh believer in India and around the world. The Khalistan movement ${ }^{8}$ is an expatriate movement ${ }^{9}$ , and a strong aspiration among the Sikhs in India to both gain Sikh statehood ${ }^{10}$ and create the land of the pure. Such a state existed between 1709-1849, between the downfall of Mughals and the annexation of the Sikhs by the British in India. ${ }^{11}$

How do we resolve questions related to religious and political freedom? Sikhs' religious aspiration can be achieved by creating a Vatican-style city-state, where the Akal Takht and the area surrounding the Harimandir Sahib are declared as a sovereign state. Here the Chief Guru and its religious leaders can be given limited sovereignty. While the Khalsa's state foreign policy and defense continue to remain in the hands of the Indian Government, the rest of the Sikhs in Punjab remain as a secular state. The Akal Takht can provide the basis for modeling a Vatican style state, and the Akal Dal can provide the basis for the continuation of a secular state for the Sikhs. One is to establish a holy place for peace and spiritual power; the other is to continue to hold civil power in the context of the Indian Government. Sikhism is a peaceful religion. Sikhism can practice its teaching and show the world that there can be a limited but defined state for Sikhism within the Indian constitution. However, if both religious and political freedom is granted to the Punjab state as a whole, it would create a fundamental state. There is no place for a fundamental state in the secular world. India, as a nation is known for religious tolerance and peace, can make political and religious changes as needed. India has given its citizens religious freedom. However, the history of Sikhs has been long and cruel. This struggle can end if the Sikhs and the Indian Government envision a Khalsa state as modeled by the Vatican state.

In the light of the many attempts to resolve the Sikhs' aspiration, including the possibility of having a referendum ${ }^{12}$, this paper attempts to present a realistic solution keeping Sikhs' aspirations and India's sovereignty in perspective. The use of the Vatican state model to take care of the aspiration of the Sikhs' aspiration can provide a détente of how to deal with other

\footnotetext{
${ }^{4}$ Hamish Telford, The Call for Khalistan: The Political Economy of Sikh Separatism (1992). 8 .

${ }^{5}$ India Today, (15 February 1985), 71.

${ }^{6}$ Punjabi for "Throne of the timeless one". Also understood as the chief centre of religious authority of Sikhism.

${ }^{7}$ Diditi Mitra, The Boundaries between "home" and "Diaspora": American Sikhs and the Construction of Place, 324.

${ }^{8}$ Muhmmad Iqbal Chawla, The Khalistan Movement of 1984: A critical appreciation, (A Research Journal of south Asian

Studies Vol. 32, No. 1, January -June 2017), 81.

${ }^{9}$ Khalistan Movement, (Wikipedia 2019).

${ }^{10}$ Hamish Telford, The Call for Khalistan: The Political Economy of Sikh Separatism (1992).v.

${ }^{11}$ Khalistan Movement, (Wikipedia 2019).

${ }^{12}$ Diditi Mitra, The Boundaries between "Home" and "Diaspora": American Sikhs and the Construction of Place, 324.
} 


\section{International Journal of Social Sciences and Management Review}

religious conflicts in the world in the context of a secular state. To create an enclave of a spiritual/ state within the confines of a secular state will be an achievement of both the host country and the Sikh community, of the importance of religion in any given state. The best way to strengthen a secular state is to allow for spiritual enclave within the confines of a secular state.

\subsection{METHODOLOGY, SCOPE, AND SIGNIFICANCE}

The study of the historical precedence of the religious aspiration of the Catholic Church to gain a small but sovereign state, namely the Vatican state ${ }^{13}$ within the state of Italy, is limited to the study of the Sikhs' aspiration. The provision that Mussolini presented to the papal Church was unprecedented. ${ }^{14}$ Because of this historical precedence, other religious aspirations can hope to have a similar provision. If we can envision the Khalsa state ${ }^{15}$ modeled after the Vatican state, such a state would include the area of the Sri Harimandir Sahib and the temple complex. The historical precedence of the Vatican state can provide many religions a similar platform upon which the religious leaders can define and defend their beliefs for their believers. This will stop the rise of fundamental states around the world. If this precedence provides the basis of solving religious conflicts, this can promote the separation of the church/religion and the state and truly provide the impetus for a secular state.

History has taught us that when religion and the state are combined, both cannot function properly. Both the state and religion impose laws. One is termed as legal the other moral. Both require obedience, but they differ when it comes to punishment. One imposes incarceration or the incapacitation of the wrongdoer, the other argues for the eternal damnation of the immoral person. Temporal punishment cannot involve eternal punishment. Temporal punishment is to be imposed by the state, and religious punishment is to be imposed by God and only God. We cannot allow religious leaders to impose divine punishment. History has taught us in medieval times what happens when religious leaders join hands with the state and impose punishment for religious reasons. Excommunication and burning at the stake, along with all the cruelty of different kinds of punishment to keep its member loyal to both the state and $\operatorname{God}^{16}$. We have come a long way. This is what Secularism is all about, the separation of the state and religion. Fundamental states that do not distinguish between state and religious laws. What must be noted of Secularism is that no one has a monopoly over truth related to God or have any special access to God. So, while the secular state allows citizens to define and defend their way of life, it supports everyone's belief. A secular state believes in the rule of law, not the rule of God.

Religion and religious freedom are fundamental to the human condition. The right to preach, practice, and propagate religious beliefs is a fundamental part of what it means to be human. But history has taught us that though religion is an important part of the human condition. History has taught us that the separation of religious and political powers is necessary if all

\footnotetext{
${ }^{13}$ Thomas Bokenkotter, A Concise History of the Catholic Church, (New York: Doubleday. 2005), 386.

${ }^{14}$ Ibid,. 386.

${ }^{15}$ Hardev Singh Virk, The Khalsa Ideal -State and Democracy. (Sikhnet, 2015).

${ }^{16}$ John Foxe, Fox's book of Martyrs, Eds. Paul L. Maier and R. C. Linnenkugel, (Grand Rapids MI: Kregel Publication, 2016). This book records the means and methods used to keep people in the church.
} 


\section{International Journal of Social Sciences and Management Review}

religions are to have this right ${ }^{17}$. No religion can have a monopoly over truth related to God. If it does, it is called or becomes a fundamental state which is detrimental to the well being of any society. A secular state allows each religion to preach, practice, and propagate what they believe as they see fit. Every religion and its followers must have an enclave where their leaders can define and defend their religious paradigm. One way we can do this is to use the Vatican model that created a religious order like no other. The creation and the existence of the Vatican state has taken care of the Catholic world and allowed the Church to define and defend their truth. This can serve as a model for at least two other religions--, namely Muslims and Sikhs, that are asking an enclave to define and defend their faith for their followers. The Muslims want a caliphate ${ }^{18}$, and the Sikhs want a country. What is the significance of this study? Nationalism has its roots in all aspects of human life-language, race, and religion play an important role. The sacredness of land is always part of nationalism. Vatican state is sacred for the Catholics, Mecca is sacred for the Muslims, Potala Palace is sacred for Tibetan Buddhists, and Jerusalem is sacred for Jews. It is not a surprise that the Sikhs consider the Harimandir Sahib as the abode of the pure.

\subsection{History of Sikh Separatism}

The Khalistan movement is a movement to gain Sikh statehood ${ }^{19}$ and create the land of the pure $^{20}$. Such a state existed between 1709-1849, between the downfall of Mughals and the annexation of the Sikhs by the British in India. ${ }^{21}$ In modern times the Sikhs' separatism movement for a qaum (nation) ${ }^{22}$ became prominent after the blue star operation ${ }^{23}$ when the separatist leader Sant Jarnail Bhindranwale and his followers were killed by the order issued by the then Prime Minister of India, Mrs. Indira Gandhi. The Sikhs' separatist movement has had several militant phases, such as the Khalistan commando force (KCF), Khalistan Liberation Force (KLF), and the Khalistan Liberation Organization (KLO). ${ }^{24}$ The Sikh separatist movement can be traced over the last hundred years in four stages ${ }^{25}$. In 1873 the formation of the Sikh Sabha ${ }^{26}$ organization intended to restore Sikh heritage and values with Punjab. The Singh Sahib period extended between 1873-1920). The second stage saw the Singh Sabhas replaced by Akali Dal, directed by Master Tara Singh. ${ }^{27}$ This stage consolidated the Sikh community identity. The third stage saw the Akali Dal divided. The main faction was lead Sant Fateh Singh ${ }^{28}$, who motivated the party towards the formation of a new secular Punjabi state based on language and culture. Statehood was achieved in $1967^{29}$. The Akal Dal detached itself from the Hindu Haryana and Himachal Pradesh and brought out

\footnotetext{
${ }^{17}$ To mix religion and politics is an medieval idea.

${ }^{18}$ This would be another topic for study. There could be a caliphate for the Sunnis and a caliphate for the Shias

${ }^{19}$ Rajshree Jetly, The Khalistan Movement in India: The Interplay of Politics and State Power, (International Review of Modern Sociology, 2008), 61-64.

${ }^{20}$ Diditi Mitra, The Boundaries between "Home" and "Diaspora": American Sikhs and the Construction of Place, 324.

${ }^{21}$ Khalistan Movement, (Wikipedia 2019).

${ }^{22}$ Rafael Fuentes, Sikh Nationalism in India (2017), 1.

${ }^{23}$ Hamish Telford, The Call for Khalistan: The Political Economy of Sikh Separatism (1992),9.

${ }^{24}$ Rajshree Jetly, The Khalistan Movement in India: The Interplay of Politics and State Power, (International Review of Modern Sociology, 2008), 73.

${ }^{25}$ Hamish Telford, The Call for Khalistan: The Political Economy of Sikh Separatism (1992), 36.

${ }^{26}$ Ibid., 37.

${ }^{27}$ Ibid., 37.

${ }^{28}$ Ibid., 37.

${ }^{29}$ Ibid. 37.
} 


\section{International Journal of Social Sciences and Management Review}

the Anandpur Sahib Resolution (ASR) in $1978^{30}$; and, for the first time, asserted that the Sikhs were a qaum (nation) ${ }^{31}$. This set up the ideological basis for the formation of Khalistan-a Sikh independent state. In the 70s, the Akalis joined themselves with the SGPC (Shiromani Gurdwara Parbandhak Committee-since), the body that elects and controls the gurdwaras since 1920s, and begins to project the political demands of the Punjabis. The fourth stage of Sikh separatist's nationalism was initiated in 1980 when Sant Jarnail Bhindranwale ${ }^{32}$, the head of a small Sikh seminary named Damdami Taksal. He self-appointed himself as the leader of the Sikh Panth (spiritual way) and challenged the Akali Dal party. He revitalized Sikhism and, more importantly, emphasized Sikh identity as defined by Singh Sabhas. Bhindranwale put emphasis on taking baptism and becoming part of the Khalsa or the brotherhood of the Pure. With his speech in 1978, he radicalized Sikhism when he assaulted and killed Nirankaris to establish orthodoxy ${ }^{33}$ and argued for austerity by establishing a Sikh nation. In the 80s, he was joined by the All India Sikh students federation (AISSF), who were fervent supports of Sant Jarnail Bhindranwale, who spearheaded the movement for Khalistan $^{34}$. However, Indira Gandhi rejected the concept of quam (nation) ${ }^{35}$ for the Sikh panth (community), in that she regarded the idea of a Sikh nation as treasonous ${ }^{36}$. As such, in 1984, the Indian army fought their way into the Golden temple, where Bhindranwale and his supporters had entrenched. It was here that he and his followers were killed, but the dream of the homeland continues. Currently, the Akal Takht-Sikhism's highest governing body along the Akali Dal-led SGPC continues the hope for Khalistan. The place of the Gurus is of paramount importance. There were ten Gurus, to begin with, and now the title is given to the chief Guru in the Akal Takht. However, the visible body of the Guru is the Granth Sahib.

The first two hundred years of Sikhism was the era of the Gurus and the consolidation of the religious texts, symbols, and rituals. ${ }^{37}$ The next hundred years witnessed the Sikh struggle for survival against mogul oppression and the political consolidation in the Sikh rule of Punjab in $1799^{38}$. With the coming of the British, the Sikhs supported the British during the Mutiny. But Hindu revivalism and Christian missionaries saw in 1873 the establishment of Singh Sahib that promoted modern Sikh identity and Sikh nationalism. ${ }^{39}$ The Singh Sahib ended in $1920^{40}$. In 1920 the Sikhs established the SGPC (Shiromani Gurdwara Parbandhak Committee), the parliament for Sikhs,( to control the Sikh gurdwaras--(temples), joined hands with the Akali Dal, the political wing of the Sikh community to address Sikhs' nationalism. ${ }^{41}$ Now Sikh nationalism is in the forefront again. Sikhs want a Sikh homeland this wish of the Sikhs is the will of the Sikhs. Their wish, want and will for a homeland have

\footnotetext{
${ }^{30}$ Rajshree Jetly, The Khalistan Movement In India, (International Review of Modern sociology, Vol.34, No1 (Spring 2008), 64.

${ }^{31}$ India Today 15 February 1985, p71.

${ }^{32}$ Hamish Telford, The Call for Khalistan: The Political Economy of Sikh Separatism (1992), 38.

${ }^{33}$ A sect of Sikhism proclaimed as enemies of the Sikh community or panth.

${ }^{34}$ Muhmmad Iqbal Chawla, The Khalistan Movement of 1984: A critical appreciation, (South Sasin Journal Vol. 32, No. 1., January -June 2017), 81.

${ }^{35}$ Hamish Telford, The Call for Khalistan: The Political Economy of Sikh Separatism (1992), 8.

${ }^{36}$ Ibid., 148.

${ }^{37}$ Hamish Telford, The Call for Khalistan: The Political Economy of Sikh Separatism (1992), 2.

${ }^{38}$ Ibid., 2.

${ }^{39}$ Ibid., 2.

${ }^{40}$ Hardev Singh Virk, The Sikh Gurus, The Sikh and the Khalsa (2014), 2.

${ }^{41}$ Ibid., 4.
} 


\section{International Journal of Social Sciences and Management Review}

became a demand ${ }^{42}$ after the deep woundt to the Sikh psyche ${ }^{43}$ left by the Bluestar operation $^{44}$ that saw the death of so many militant Sikhs. Sikhs' 500-year story is a story of this struggle to create a homeland for the pure at heart. The Sikhs' wish, want, and will for a holy land can be actualized by the implementation of the six-point resolution.

\subsection{Six Point Resolution for Sikhs' aspiration.}

(1) Petition the Indian Government to create a new state, called the Khalsa state (like the Vatican state). Here the Chief Guru would be the temporal head and the spiritual leader of Sikhism. (2) Allow the Sikhs to create a holy land and not a homeland around the area occupied by the Akal Takht and the temple complex. (3). Declare the Akal Takht as the land of the pure' as envisioned by the Sikhs community. This would allow the Sikhs to define and defend their faith as an enclave within the Punjab state (India) without demanding a sovereign state for all the Sikhs. (4) Continue to allow the Sikhs to have an elected state government to preserve the Sikhs' culture and tradition in the context of a secular state. (5) Acknowledge India's continued claim that Punjab state is an integral part of India by consigning foreign and defense matters to the Indian Government. (6) Appeal to India's goodwill and expect India to direct and dictate the results. Understand that fraternity, not freedom for the Sikhs that is in question.

\subsection{Khalsa State—Based on Vatican Statehood Model.}

In 1929, Italy gave the Catholic Church both religious and political freedom when part of Italy was carved out and given to the Church to be the spiritual headquarters of the Catholic world. ${ }^{45}$ The unification of Italy saw the need for the papacy to secede many of its former territories gained throughout the history of the Church. Under King Victor Emmanuel III and Mussolini, Pope Pius X1, and the Cardinal Secretary of state, Pietro Guaspari negotiated and created the Vatican state. ${ }^{46}$ The Vatican state ${ }^{47}$ came into reality in 1929 by the Lateran Treaty between the Holy See ${ }^{48}$ and the Government of Italy. ${ }^{49}$ What must be noted is that the Vatican state is distinct and different from the $\mathrm{Holy}_{\mathrm{See}^{50}}$, which dates back to the early Church and is the central Episcopal See of 1.2 billion believers around the world. There is no reason not to see this possibility as a solution to the Sikhs' aspiration. This would allow the Sikhs to define and practice Sikhism as it has been for 500 plus years. Amritsar has been the political and spiritual capital for the Sikhs for many centuries.

\footnotetext{
${ }^{42}$ Rajshree Jetly, The Khalistan Movement In India, (International Review of Modern sociology, Vol.34, No1 Spring 2008), 62.

${ }^{43}$ Hamish Telford, The Call for Khalistan: The Political Economy of Sikh Separatism (2014), 159.

${ }^{44}$ Name of the military operation in 1984 when the Indian army invaded the Golden temple complex.

${ }^{45}$ Umberto Toschi, 1931, 529. This is an enclave or a city-state in Rome, An 108 acre enclave on the bank of Tiber River, with about a thousand citizens. This enclave is a country, which is both an ecclesiastical 'or sacerdotal-monarchical state, administered by the Pope. All leadership is with the Catholic clergy from different national origins. From 1377 popes reside at the Apostolic Palace or Quirinal Palace in Rome. Within Vatican City are the famous heritage sites such as St. Peter's Basilica, the Sistine Chapel and the Vatican Museums.

https://en.wikipedia.org/wiki/Vatican-City)

46 Thomas Bokenkotter, A Concise History of the Catholic Church, (New York: Doubleday. 2005), 386.

${ }^{47}$ Stato Della Citta Del Vaticano-Italian expression for a walled enclave.

${ }^{48}$ Robert Nevelle, The World of the Vatican, (New York: Harper \& Row. Publishers 2005), 38-56.

${ }^{49}$ Ibid., 18.

${ }^{50}$ Ibid., 38-56.
} 


\section{International Journal of Social Sciences and Management Review}

How and why the Vatican state was created sets a good precedence on how and why the Khalsa State can be actualized. According to the Lateran Treaty, the Holy See would have "full ownership, exclusive dominion, sovereign authority, and jurisdiction" over the citystate. What made this agreement last. First, part of the agreement was that the Vatican state remains a neutral state. ${ }^{51}$ They recognized the leadership of the Pope and His obligation to allow believers around the world to visit the Vatican state. This called for the necessity for neutrality. While believers from different parts of the world were welcomed to Rome, the Pope and its people would remain neutral in matters of politics. The Catholic Church remained neutral during World War II and benefited by not being bombed by the allied forces. ${ }^{52}$ Second, the foreign policy and defense were to be in the hands of the Italian Government while the integral security was taken care of by Swiss guards. The Vatican state could also send ambassadors of their choice to different countries.

Can what was and is good for the Pope and his people be good for the Sikhs and Sikhism ${ }^{53}$ Historically, Sikhs have always been part of India, but the history of the Sikhs with their fellow Indians under both the Muslim rulers and the present Indian Government has had a checkered history. But, if a new relationship is to be had, we have to present their aspiration as the need for a holy land, where the land of the pure is to define and defend Sikhism as a religion within the context of a limited sovereign Sikh state. If the Khalsa state is created, the chief Guru would be able to maintain a temporal role but only within the Akal Takht and temple complex, while the rest of Punjab would be a secular state. In such a world, the Khalsa state can enjoy the same freedom with limited sovereignty if neutrality is maintained. Why would such a sovereign state have meaning? To the Sikh people, this would be a realistic goal to achieve. It would comply with the nature of Sikhism -which preaches, practices, and propagates pacifism to the world at large. Nothing would better fit than creating a limited sovereign state, modeled after the Vatican state.

\subsection{Invite the Akal Takht and Akal Dal to form the Khalsa state}

The Akal Takht - the supreme authority of Sikhism ${ }^{54}$ and the Akali Dal---the political branch of the Sikhs, has, in modern times, advocated for both political and religious freedom. While the Akal Takht has been the supreme authority for the Sikhs from the early days of Sikhism, the Akal Dal founded on December 14, 1920, has been seen as an Indian political party ${ }^{55}$ that defines the will of the Sikhs best. As a political party, they have ruled Punjab state for decades, and ever since its formation has remained the political voice of the Sikhs ${ }^{56}$. Realistically they have political freedom within the homeland of India. What they need to have is to declare Akal Takht as the land of the pure by creating the Khalsa state where the chief Guru is the temporal leader of the Akal Takht and the spiritual leader of the Sikhs at large. It is possible for the Sikhs to negotiate with the Indian Government to create a Vatican style state that allows Sikhs to define and defend their faith as they see fit. The neutrality of

\footnotetext{
${ }^{51}$ Herbert Wright, The Status of the Vatican City, (The American Journal of International Law 38, no.3, 1944), 455.

${ }^{52}$ Ibid., 455.

${ }^{53}$ Religious leaders play an important role in the lives of their believers, and they must be given a rightful place, but believers need to advise religious leaders to abstain from playing a role in politics.

${ }^{54} \mathrm{http}: / /$ www.sikh-history.com/sikhhist/events/akaltakht.html

${ }^{55}$ Preetinder Grewal, 98 years of Akali Dal: historical gains to a battle of survival, (13 December 2018).

${ }^{56} \mathrm{Ibid}$
} 


\section{International Journal of Social Sciences and Management Review}

Volume: 03, Issue: 06 “November - December 2020”

ISSN 2582-0176

the Khalsa State understood in the context of the sovereignty would imply that the foreign and defense policy be in the hands of the Indian Government. The Vatican state enjoys security without any expense. Similarly, Sikhs can expect the same from the Indian Government. Sikhs can enjoy the same privileges of a limited sovereign state if they choose to subject their foreign policy and defense to the Indian Government.

While it is argued that a limited sovereign state would make the chief Guru as the head of the Khalsa state, the rest of Punjab can continue its state/federal relationship - "one sovereign spiritual country within one sovereign and secular country. While the Khalsa state can write its constitution for its temporal state, Punjab can be an integral part of India and can share with the rest of India the same currency, passports, legal and parliamentary system of Government. India is a democratic state. The Sikhs can expect the same political freedom offered to all Indians to run for political office like any other Indian.

Given the reality of the sovereignty of India, the Sikhs must work towards their aspirations within the context of creating a Holyland, not a homeland. The India government should and will respond to challenges posed to them by the Sikhs. Sikhs can expect religious, social, and economic freedoms and can hope to actualize their religious aspirations. They can achieve freedom from want, fear, and war without asking for total political freedom. With such a proposal, both Sikhs and India stand to gain. Spiritual state within the confines of a secular state is in the best interest of both the Sikhs and India. This would give Sikhs a way to regulate their' way of life' and national aspirations. Unresolved national aspirations of the Sikhs have become an international concern, but if their concerns are defined in the context of creating a temporal place for establishing spiritual authority, then good results can be expected. International communities cannot take sides. There are no known modus operandi plan (methods of operation) that can guarantee success. Sikhs must 'adopt' a new paradigm and 'adapt' existing plans to achieve their goals.

\subsection{Declare Harmandir Sahib as an 'abode of the pure.'}

The Sikhs desire to assert the Harmandir Sahib - the temple of $\mathrm{God}^{57}$ as the place and power of God is legitimate. When the Khalsa state around the Temple complex with temporal and spiritual powers like the Vatican state is established, "the Khalsa shall rule." The expressive will of the Sikh people to sovereignty is part of the anthem, which follows the litany or ardas recited at the end of every religious service of the Sikhs. ${ }^{58}$ The inseparability of religion and politics has been one of the chief characteristics of Sikhism. ${ }^{59}$ While the Punjab State takes care of the security of the state at large, the Khalsa state can take care of the security concerns of the temple complex or enclave as they see fit. This would mean that the Khalsa state would recruit security guards of their own, like the Vatican state. The Sikhs in the state of Punjab can continue to be a secular state governed by the Indian Government like the rest of the states in India. Secularism means respect for all religions. A secular state cannot support any particular faith at the expense of other faiths. Both religion and the state play an important role in the well-being of its citizens. The Government regulates behavior, and religion define

\footnotetext{
${ }^{57}$ David S. Noss and John B. Noss. A History of the Worlds Religion. (New York: New York, Macmillan Publishing company, 1990), 241.

${ }^{58}$ Raj Karega Khalsa, (Wikipedia, 2019).

${ }^{59}$ Gurdashan Singh Dhillon, Religion and Politics: The Sikh perspective, 1.
} 


\section{International Journal of Social Sciences and Management Review}

the moral life of its citizens. The question is not whether we need a government-the question is, can a particular religion be the basis for regulating behavior. We cannot see the need for religion without the need for respecting all religions. Any religion is one among many. Unless each religion accepts this and understands that different religions can actualize this need, there will always be tension in society. Conversion happens but should not be based on the notion that a particular religion has a monopoly over truth. If we want to live in peace and consider one's country as a land of peace, then Secularism must be the basis for the state government. Religion is meaningful when it is defined and defended in the context of Secularism. Religion, independent of Secularism is a formula for chaos.

\subsection{Consign Foreign and Defence Under the Control of India}

When India got its independence, Sardar Patel negotiated with the princely states to consign foreign and defense under the control of the Indian Government. This can be done with the Khalsa state also. The Punjab state is an integral part of India. In the context of India's sovereignty, the foreign policy should be left with the Indian Government. The Sikhs can have social/religious independence and still be an integral part of India. If the Sikhs do not challenge India's sovereignty, they can negotiate their religious and social freedom. If Guns make the weakest and the strongest equals ${ }^{60}$ religious freedom, or the freedom of conscience can make humans equally human. Unless religious freedom is achieved, we cannot be free. True freedom is freedom of conscience ${ }^{61}$ within the context of secular law. While foreign policy and defense are under the Indian Government, the Khalsa State can choose how to relate to the rest of the world, as they deem necessary. As a spiritual and temporal state, the Khalsa can choose which countries it wants to have relationships with and exchange ambassadors as goodwill representatives without any political bias.

\subsection{Appeals to India's Goodwill}

Can the wish and will of the Sikh community get the goodwill of the Indian government? When India was granted independence, the Sikhs choose to stay with Hindu India rather than affiliate with Muslim Pakistan. Both Hinduism and Muslim faith are important to Sikhism because Sikhism is a study on syncretism of these two faiths in the sub-continent. Sikh activists argue that the Sikhs were deceived at the time of partition ${ }^{62}$. The Sikh community in India is a vibrant community, which respects the fraternity of all Indians. They contribute to every aspect of the Government in India, especially the army. History teaches us that there is no permanency of nations or empires. Since independence, many movements have started to bring to attention the Sikh aspiration. From 1970, Sikhs have used the term Sikh homeland within the Indian Union ${ }^{63}$ The Ardas (litany), Raj Karega Khalsa-- a slogan that represents the Sikh idea of sovereignty ${ }^{64}$ is recited after the Ardas. It is believed to have been uttered by Guru Govind Singh himself and which has been repeated by Sikhs throughout the world, at the end of every congregational prayer ever since 1710 and hope to acquire a Sikh

\footnotetext{
${ }^{60}$ American constitution - the second amendment

${ }^{61}$ American constitution - the first amendment

${ }^{62}$ Michael T. Kaufman, In India, Sikhs Raise a Cry for Independent Nation (The New York Times, 1981), 2.

${ }^{63}$ Sirdar Kapur Singh, Sikhism and Politics: The Demand for Sikh Homeland (2017), 2.

${ }^{64}$ Raj Karega Khalsa, (Wikipedia, 2019).
} 


\section{International Journal of Social Sciences and Management Review}

homeland. ${ }^{65}$ Sikhs' aspiration would be easy to fulfill if they accept India's sovereignty and appeal to India's goodwill to establish a Khalsa State. It would seem hard if Sikh challenge India's sovereignty.

India represents a dynamic world before and after it gained its independence. India is a democratic state while it has embraced Secularism. This principle allows all faith to live in peace in India. The Indian Government would be praise worthy to grant a Vatican type of state to let the Sikhs preach and practice their faith. What must be noted is that we should never forget the importance of Secularism to define and defend one's faith. We have allowed and given the Dalai Lama and his followers a place to live and practice their faith. ${ }^{66}$ The merits of Secularism is such that it allows for such possibilities as the Vatican model for other religions for the same reasons.

\subsection{Policy Implication}

The historical precedence of the creation of the Vatican state provides a basis for establishing policies related to issues associated with church/religion and state relationships. The international community that is interested in establishing secular states can learn from the Vatican state experience that mainstream religions can be given statehood, thus avoiding the creation of fundamental states.. The course or principle of action adopted or proposed is this presentation is that we define different religious aspirations in different parts of the world in the context of the historic provision the Italian Government created to allow the Catholic Church to define and defend the life and thought of the Church. What will this accomplish? (1) This would allow different religions around the world to create enclaves to live and practice their faith in a temporal state within the context of a secular state, thus separating religious laws from legal laws for those who live outside such enclaves. (2) This would allow each religious enclave to speak with one authoritative voice the concerns and issues related to their faith and followers. This would prevent us from fighting with faceless or radical religious groups from different religions. The historical precedence of the provision of the Italian Government to provide a small but sovereign state can provide a basis for other religions to create enclaves to define and defend their faith. ${ }^{67}$

\subsection{CONCLUSION}

Both the spiritual front the Akal Takht and the political front the Akali Dal, can be used to to envision the Khalsa state for the Sikhs. Given the reality of the sovereignty of India, the Sikhs can work towards their aspirations within the context of creating a Holyland, not a homeland. Sikhs can hope for a Khalsa state modeled after the Vatican state if the Sikhs evoke to create a holy state for the Sikhs within the context of the sovereignty of India. The process of achieving their political and religious aspirations depends of how it is presented.

\footnotetext{
${ }^{65}$ Ibid., 3.

${ }^{66}$ In Dharmashala in Kangra distinct in India. Houses the Dalai Lama's residence and the head quarters of the central Tibetan Administration.

${ }^{67}$ While Rome is a secular city the Vatican City is a fundamental state. One can expects no other religion to establish itself in the Vatican state but the city of Rome can allow different believers to co-exist within the city of Rome. This is what we can expect also for the with Khalsa state. Sikhism will be fundamental in the Khalsa sate while the state of Punjab should be considered as secular state.
} 


\section{International Journal of Social Sciences and Management Review}

Volume: 03, Issue: 06 “November - December 2020”

ISSN 2582-0176

Presenting Sikhs' concerns in the context of the 'goodwill' of India, the Sikhs can achieve their dream. India can be instrumental in making Harimandir Sahib (golden temple) the abode of God. The study presents three conclusions. (1) Declare the area around the Harimandir Sahib temple complex of Amritsar as the Khalsa state (like the Vatican State) and accept the Chief priest as both the temporal leader over the Khalsa state and the spiritual leader of all the Sikhs. (2) Allow civil/secular state in Punjab to continue its relationship with the federal movement, and (3) maintain Indian sovereignty by subjecting both the foreign and defense policy to the Indian Government.

India, as a secular country, is committed to the rule of law, not the rule of God, as such, even though Sikhism would be the religion of the Khalsa state, the Punjab state government would remain as a secular state. This will avoid the trap of a fundamental state. ${ }^{68}$ This would avoid conflicts with other faiths and conflicts within Sikhism. As we see in most institutionalized religions, fundamentalism breeds arrogance and civil unrest over beliefs. Mere religion can be divisive. A secular state is a foundation that will check the rise of fundamentalism. Religion alone cannot be the basis for nationalism. Having a secular state would allow for legislative authority to write rules as to how they choose to preserve their lifestyle and values.

We do not have freedom from religion, but we do have freedom of religion. Only Secularism can provide the basis for respecting all religions. Sikhs have a right to preserve their values, language, religion, and land. Empires have collapsed, trying to establish universal laws for human life. ${ }^{69}$ We can talk and hope for a Khalsa state that defines and defends Sikhs' way of life in the context of India's hegemony. History has taught us that there is no permanency of nationhood. It has to be defined and defended constantly. Once Khalsa state is defined in the context of the sovereignty of India, the Sikhs can live with the rest of India in peace. This would indeed make Khalsa as the abode of God. Nothing would better fit into the Sikhs' paradigm than a limited sovereign state based on the model of the Vatican state. With India's 'goodwill,' the Khalsa state can be a spiritual state, similar to the Vatican state.

What Sikhs expect must be understood in the context of what the Indian Government can do for them, not what the Indian Government cannot do for them. What India can offer the Sikhs is a Khalsa state modeled after the Vatican state. What India cannot offer is a referendum that would lead to a separate country - this would disintegrate the country. ${ }^{70}$ The historical precedence of the creation of the Vatican state can provide a template for a détente in resolving religious aspirations within Secularism. The Vatican state experience can provide the basis for the creation for a fundamental enclave, namely the Khalsa state to define and defend Sikhism within the context of a secular state. Within the context of a secular India, we can find a place for peace and power for the Sikhs.

\footnotetext{
${ }^{68}$ In a secular state 'beliefs associated with Gods cannot be attached to Gods'--Epicurus.

${ }^{69}$ The Persian, Greek, and Roman empires collapsed trying to establish universal laws to govern human behavior. The ancient question put forth to king Darius of Persia when he tried to legislate universal laws of the empire boasted that the laws of the Meds and Persians were intractable. However, the king soon found out that even the laws related to the disposal of the dead could not be universal. The Egyptians wanted to mummify the dead, the Indians wanted to burn the dead, the Persians wanted to bury the dead and some in the empire wanted to eat the dead.
}

\footnotetext{
${ }^{70}$ Referendum would almost guarantee a Sikh quam or nation. This would also see the end of India as a country. India would
} break up further over other religions and language related issues. 


\section{International Journal of Social Sciences and Management Review}

Volume: 03, Issue: 06 “November - December 2020"

ISSN 2582-0176

\section{REFERENCES}

\section{Journals}

Chawla, Muhammad Iqbal. "The Khalistan Movement of 1984: A Critical Appreciation." A Research Journal of South Asian Studies32, no. 1 (2017): 81-90.

Darshi, A. R. The Gallant Defender. Ludhiana: Jaswant Printers, 2004.

Jetly, Rajshree. "THE KHALISTAN MOVEMENT IN INDIA: The Interplay of Politics and State Power." International Review of Modern Sociology 34, no. 1 (2008): 61-75. http://www.jstor.org/stable/41421658.

Mitra, Diditi. "The Boundaries between "Home" and "Diaspora": American Sikhs and the Construction of Place." Journal of Punjab Studies 22, no. 2 (2015): 319-42.

Murphy, Francis X. "Vatican Politics: Structure and Function." World Politics 26, no. 04 (1974): 542-59. doi:10.2307/2010100.

Shani, Giorgio. "Beyond Khalistan? Sikh Diasporic Identity and Critical International Theory1." Sikh Formations 1, no. 1 (2005): 57-74. doi:10.1080/17448720500132565.

Singh, Gurharpal. "A Victim Diaspora?: The Case of the Sikhs." Diaspora: A Journal of Transnational Studies8, no. 3 (1999): 293-307. doi:10.1353/dsp.1999.0005.

Telford, Hamish. The Call for Khalistan: The Political Economy of Sikh Separatism. March, 1992. Department of Political Science, Montreal.

Toschi, Umberto. (1931, October). The Vatican City State from the Standpoint of Political Geography. The Geographical Review, Vol.21 No.4 (October 1931), 529-538. doi: $10.2307 / 209364$

Wright, Herbert. "The Status of the Vatican City." The American Journal of International Law 38, no. 3 (1944): 452. doi:10.2307/2192386.

\section{Websites}

F.J, Fox. "The Catholic Church in the United States of America." Catholic Education Resource Center. 2000. Accessed February 06, 2019.

https://www.catholiceducation.org/en/culture/history/the-catholic-church-in-theunited-states-of-america.html.

Fuentes, Rafael. Sikh Nationalism in India. 2017. https://www.researchgate.net/publication/313847403_Sikh_Nationalism_in_India

Kaufman, Michael T., Special To the New York Times. "In India, Sikhs Raise a Cry for the Independent Nation." The New York Times. August 16, 1981. Accessed February 04, 2019. https://www.nytimes.com/1981/08/16/world/in-india-sikhs-raise-a-cry-forindependent-nation.html. 


\section{International Journal of Social Sciences and Management Review}

Volume: 03, Issue: 06 “November - December 2020"

ISSN 2582-0176

Oberheim, Eric, and Paul Hoyningen-Huene. "Incommensurability in Science." Oxford Bibliographies. June 26, 2012. Accessed February 04, 2019.

http://www.oxfordbibliographies.com/view/document/obo-9780195396577/obo9780195396577-0022.xml.

Singh, Sirdar Kapur. "Sikhism and Politics: The Demand for Sikh Homeland." Sikhism Freedom Voice of Khalistan. October 27, 2017. Accessed February 04, 2019. https://www.sikhfreedom.com/sikhism-and-politics-demand-sikh-homeland.

Dhillon, Gurdashan Singh. "RELIGION AND POLITICS: THE SIKH PERSPECTIVE Sikhism Articles." Gateway to Sikhism Foundation. Accessed February 04, 2019. https://www.allaboutsikhs.com/sikhism-articles/religion-and-politics-the-sikhperspective.

Virk, Hardev Singh. "The Khalsa Ideal - State \& Democracy." SikhNet. October 14, 2015. Accessed February 04, 2019. https://www.sikhnet.com/news/khalsa-ideal-statedemocracy.

Virk, Hardev. "The Sikh Gurus, The Sikhs, and The Khalsa." 2014. https://www.researchgate.net/publication/259713724_The_Sikh_Gurus_The_Sikhs_a nd_The_Khalsa

"The Nathaniel Centre." The Nathaniel Centre. Accessed February 04, 2019. http://nathaniel.org.nz/euthanasia/justice-select-committee.

"Sikh Empire." Wikipedia. January 27, 2019. Accessed February 04, 2019. https://en.wikipedia.org/wiki/Sikh_Empire.

"Raj Karega Khalsa." Wikipedia. January 28, 2019. Accessed February 06, 2019. https://en.wikipedia.org/wiki/Raj_Karega_Khalsa.

"Khalistan Movement." Wikipedia. January 31, 2019. Accessed February 06, 2019. https://simple.wikipedia.org/wiki/Khalistan_movement.

\section{Compilation and Books}

Bokenkotter, Thomas S. A Concise History of the Catholic Church. New York: Doubleday, 2005.

Coulombe, C. A. (2003). Vicars of Christ a History of the Popes. New York: Citadel Press.

Duggal, Kartar Singh. Maharaja Ranjit Singh the Last to Lay Arms. New Delhi: Abhinav Publications, 2001.

Neville, Robert. The World of the Vatican. New York: Harper \& Row. Publishers, 1962.

Noss, David S., and John B. Noss. History of the Worlds Religions. New York: New York, Macmillian Publishing Company, 1990. 


\section{International Journal of Social Sciences and Management Review}

Volume: 03, Issue: 06 “November - December 2020"

ISSN 2582-0176

Sher, George. Moral Philosophy: Selected Readings. Belmont, CA: Wadsworth/ Thomson Learning, 2001. 